\title{
Population-based Estimates for High Risk of Severe COVID-19 Disease due to Age and Underlying Health Conditions
}

\author{
Estimativas da População Portuguesa em Risco \\ Elevado de Doença Grave por COVID-19 Devido à Idade \\ e a Doenças Crónicas
}

\author{
Pedro A. LAIRES $\triangle{ }^{1,2}$, Carla NUNES 1,2 \\ Acta Med Port 2020 Nov;33(11):720-725 - https://doi.org/10.20344/amp.14222
}

\section{ABSTRACT}

Introduction: COVID-19 is a viral respiratory disease, which became a global threat to public health. Specific subsets of the population are more vulnerable, namely those with chronic diseases. We aimed to estimate the share of the Portuguese population at the highest risk for complications following COVID-19 infection due to both old age and specific comorbidities.

Material and Methods: Our sample included all people aged 65 years and above (2215 men and 3486 women) who participated in the fifth Portuguese National Health Interview Survey, conducted in 2014. In order to project the potential population at highest risk for COVID-19, we used the latest available official demographic estimates from the National Institute of Statistics - INE 2018. We used a more restrictive definition of risk combining old age criteria and the following chronic conditions as potential risk factors for COVID-19 according to the available literature: hypertension, diabetes, chronic obstructive pulmonary disease, cardio- and cerebrovascular disease.

Results: We estimated that $15.5 \%$ ( $n=1560667$ ) of the Portuguese population might be at increased risk for complications from COVID-19 because of old age and existing chronic conditions. Such estimates vary across the country (from $1.7 \%$ in Azores to $33.7 \%$ in Northern Portugal). Northern Portugal not only has the highest prevalence of selected morbidity (72.8\%) within mainland Portugal, but also has the largest population at risk for COVID-19 $(n=526607)$. This was followed by the Lisbon and Tagus Valley region $(n=$ 408 564) and Central Portugal $(n=388$ 867).

Discussion: Our results should encourage authorities to continue protecting those more vulnerable to the pandemic threat, particularly on those areas of the country which are more likely to be further affected.

Conclusion: We projected a considerable number of Portuguese people at the highest risk for severe COVID-19 disease due to both old age and pre-existing chronic conditions. Such estimates vary across the country.

Keywords: Age Factors; Chronic Disease/epidemiology; Coronavirus Infections/ epidemiology; COVID-19; Portugal; Risk Assessment; Risk Factors; Severity of Illness Index

\section{RESUMO}

Introdução: COVID-19 é uma doença respiratória viral que se tornou uma ameaça global à saúde pública. Grupos específicos da população são mais vulneráveis, nomeadamente os mais envelhecidos que estão expostos a determinadas doenças crónicas. O objetivo deste trabalho foi estimar a população portuguesa com potencial risco elevado de complicações após a infeção por COVID-19 devido à idade e comorbilidades específicas.

Material e Métodos: A amostra em estudo foi constituída por todas as pessoas com idade superior a 65 anos (2215 homens e 3486 mulheres) que participaram no $5^{\circ}$ Inquérito Nacional de Saúde (INS 2014). Para calcular a população potencial de maior risco para o COVID-19, foram usadas as mais recentes estimativas demográficas oficiais, disponíveis no Instituto Nacional de Estatística - INE 2018. Foi utilizada uma definição mais estrita de risco, para tal utilizando o critério de idade e a presença das seguintes condições crónicas como potenciais fatores de risco para o COVID-19, de acordo com a literatura disponível: hipertensão, diabetes, doença pulmonar obstrutiva crónica, doença cardiovascular e cerebrovascular.

Resultados: Estimamos que 15,5\% ( $n=1560667)$ da população portuguesa possa estar em elevado risco de complicações por COVID-19 devido à idade e a condições crónicas pré-existentes. Tais estimativas variam em todo o país (de 1,7\% nos Açores a 33,7\% na região Norte). A região Norte não só apresenta a maior prevalência da morbilidade analisada em Portugal continental (72,8\%), como também a maior população em elevado risco de doença severa COVID-19 ( $n=526$ 607). Seguiu-se Lisboa e Vale do Tejo ( $n=408$ $564)$ e a região Centro do país $(n=388$ 867).

Discussão: Estes resultados devem incentivar as Autoridades de Saúde a proteger os mais vulneráveis à ameaça da pandemia, particularmente nas áreas do país com maior probabilidade de serem mais afetadas.

Conclusão: Neste trabalho estimámos que, devido à idade e a determinadas condições crónicas pré-existentes, há um número considerável de portugueses que se encontra em elevado risco de doença severa em caso de infeção COVID-19. Estas estimativas variam ao nível regional.

Palavras-chave: Avaliação do Risco; COVID-19; Doença Crónica/epidemiologia; Factores Etários; Factores de Risco; Índice de Gravidade de Doença; Infeç̧ões por Coronavírus/epidemiologia; Portugal

\footnotetext{
1. Centro de Investigação em Saúde Pública (CISP). Escola Nacional de Saúde Pública (ENSP). Universidade NOVA de Lisboa. Lisboa. Portugal.

2. Escola Nacional de Saúde Pública (ENSP). Universidade NOVA de Lisboa. Lisboa. Portugal.

$\triangle$ Autor correspondente: Pedro A. Laires. pedro.laires@ensp.unl.pt

Recebido: 28 de maio de 2020 - Aceite: 02 de julho de 2020 | Copyright @ Ordem dos Médicos 2020
} 


\section{INTRODUCTION}

Coronavirus Disease 2019 (COVID-19) is a viral respiratory disease caused by the Severe Acute Respiratory Syndrome Coronavirus 2 (SARS-CoV-2), which has become a global threat to human health. ${ }^{1,2}$

The number of confirmed cases of COVID-19 has reached 11500302 worldwide (535 759 deaths) and 44 129 (1620 deaths) in Portugal as of July 8, 2020, according to WHO COVID-19 situation report $169 .^{3}$

Since the beginning of the pandemic, several relatively large-scale case studies have reported the clinical features of patients with COVID-19, and some potential factors associated with worse outcomes following infection started to be identified, namely those regarding specific chronic conditions, such as respiratory and cardiovascular diseases. ${ }^{1,4-8}$ More importantly, it quickly became very clear that specific subsets of the population are more vulnerable than others to the virus. Increasing studies showed that most patients with COVID-19 had no symptoms or mild pneumonia; however, a proportion of patients may develop severe or critical pneumonia, acute respiratory distress syndrome, or even death. ${ }^{4,9}$

Given the rapid spread and high mortality rate of COVID-19 in the vulnerable population, it is of utmost importance to identify the population groups with the highest risk for serious complications following infection. Thus, in this study we aimed to estimate the size of the Portuguese population at the highest risk for complications following COVID-19 infection. For such endeavor, we considered a restrictive definition of risk by combining old age criteria and specific comorbidities.

\section{MATERIAL AND METHODS}

We used cross-sectional data from the fifth Portuguese National Health Interview Survey (Inquérito Nacional de Saúde, INS), conducted in 2014. ${ }^{10}$ The INS is a population based survey on a probabilistic representative sample of noninstitutionalized individuals aged 15 years and over. Data collected included self-reported information on a broad range of variables related to health condition, lifestyle, and socioeconomic status. The methodology of the INS has been detailed elsewhere. ${ }^{10}$ In order to project the potential population at highest risk for COVID-19, we used the latest available official demographic estimates from the National Institute of Statistics (INE 2018). ${ }^{11}$

In this study, we adopted a definition of high risk, based on two different approaches: 1) similar to the one used by Adams ML et al, ${ }^{12}$ which was based on the presence of specific chronic conditions; 2) age criteria, by using the cutoff of $\geq 65$ years old, as defined by the CDC. ${ }^{13}$ Thus, we used a more conservative definition of high risk than Adams ML et al. This definition of highest risk, combining comorbidities and old age criteria, is thus a more restrictive one and has the potential to underestimate the population at risk [Appendix 1 illustrates results using a less conservative definition by considering old-age as just another risk factor along with the analyzed comorbidities (see Appendix 1: https://www. actamedicaportuguesa.com/revista/index.php/amp/article/ view/14222/Appendix_01.pdf)]. The available literature has shown that several risk factors, including older age and the presence of at least one of several underlying health conditions were associated with increased risk of worse outcomes. ${ }^{14,15}$

We used only those chronic conditions, which according to the available evidence, are potential risk factors for COVID-19, based on the study by Wang $B$ et al, a recent metanalysis: hypertension (OR: $2.29, p<0.001$ ), diabetes (OR: 2.47, $p<0.001)$, chronic obstructive pulmonary disease (COPD) (OR: 5.97, $p<0.001$ ), cardiovascular disease (OR: 2.93, $p<0.001$ ), and cerebrovascular disease (OR:3.89, $p=0.002) .{ }^{16}$ Thus, we did not use other comorbidities that may also cause increased risk, such as cancer, chronic kidney disease, liver disease, hemoglobin disorders, and severe obesity.

We assessed the prevalence of the aforementioned conditions in the INS sample, given that their presence for each respondent was assessed in the INS survey through self-reporting.

Following the methodology used by Adams ML et al, ${ }^{12}$ the key comorbidity variable was a composite measure including those reporting that they had cardio and cerebrovascular disease (heart attack, angina, coronary heart disease, or stroke), diabetes, chronic obstructive pulmonary disease (COPD), or hypertension. We counted the number of chronic conditions for each respondent who reported at least one condition and was considered to be at heightened risk for complications from COVID-19.

As explained, additionally, we focused on those aged older than 65 years (2215 men and 3486 women).

All statistical analyses were carried out using Stata version 13.1 to account for the complex sample design of the INS, using the survey data analysis (SVY) module. All estimates were weighted to match the population distribution in terms of geographic region, age-group, sex, level of education, and dimension of household. ${ }^{10}$ We used Jackknife estimation for survey data to estimate confidence intervals $(95 \% \mathrm{Cl})$. The significance level for all analysis was set at $5 \%$.

The Ethical Committee of the National School of Public Health approved the project. Anonymity of participants and confidentiality of data on all used databases were guaranteed. Informed consent was obtained from all INS participants has detailed elsewhere. ${ }^{10}$

\section{RESULTS}

Among the elderly ( $\geq 65$ years old), $39.3 \%$ reported 1 chronic condition, $23.1 \%$ reported two chronic conditions, $6.6 \%$ reported three chronic conditions, and $1.0 \%$ reported four or more chronic conditions. The prevalence of separate chronic conditions in the same age group were $55.2 \%$ (95\% Cl: $53.3 \%$ - 57.1\%) for hypertension, 23.3\% (95\% Cl: $21.7 \%-25.0 \%)$ for diabetes, $19.0 \%$ (95\% Cl: $17.6 \%$ - $20.6 \%$ ) for cardio and cerebrovascular diseases, $11.8 \%$ 
(95\% Cl: $10.6 \%-13.1 \%)$ for COPD. The average prevalence of at least any of these chronic diseases was $70.0 \%$ (95\% Cl: $68.2 \%-71.8 \%)$.

If projected to the overall population, we estimated that 1560667 people might be at highest risk for complications following COVID-19 infection (Fig. 1 and Table 1). Thus, we estimated that $15.2 \%$ of the Portuguese population is at increased risk for complications from coronavirus disease given the combined risk of old age and the analyzed risk factors (cardio and cerebrovascular diseases, hypertension, diabetes, or COPD).

More women are affected by the analyzed risk factors ( $71.8 \%$ vs $67.6 \%$ in men, $p=0.023$ ), and because there are more women than men over 65 in Portugal (1 298413 vs 930 337, respectively), the projected population at risk is much higher in the female group (932 131; share of $59.7 \%$

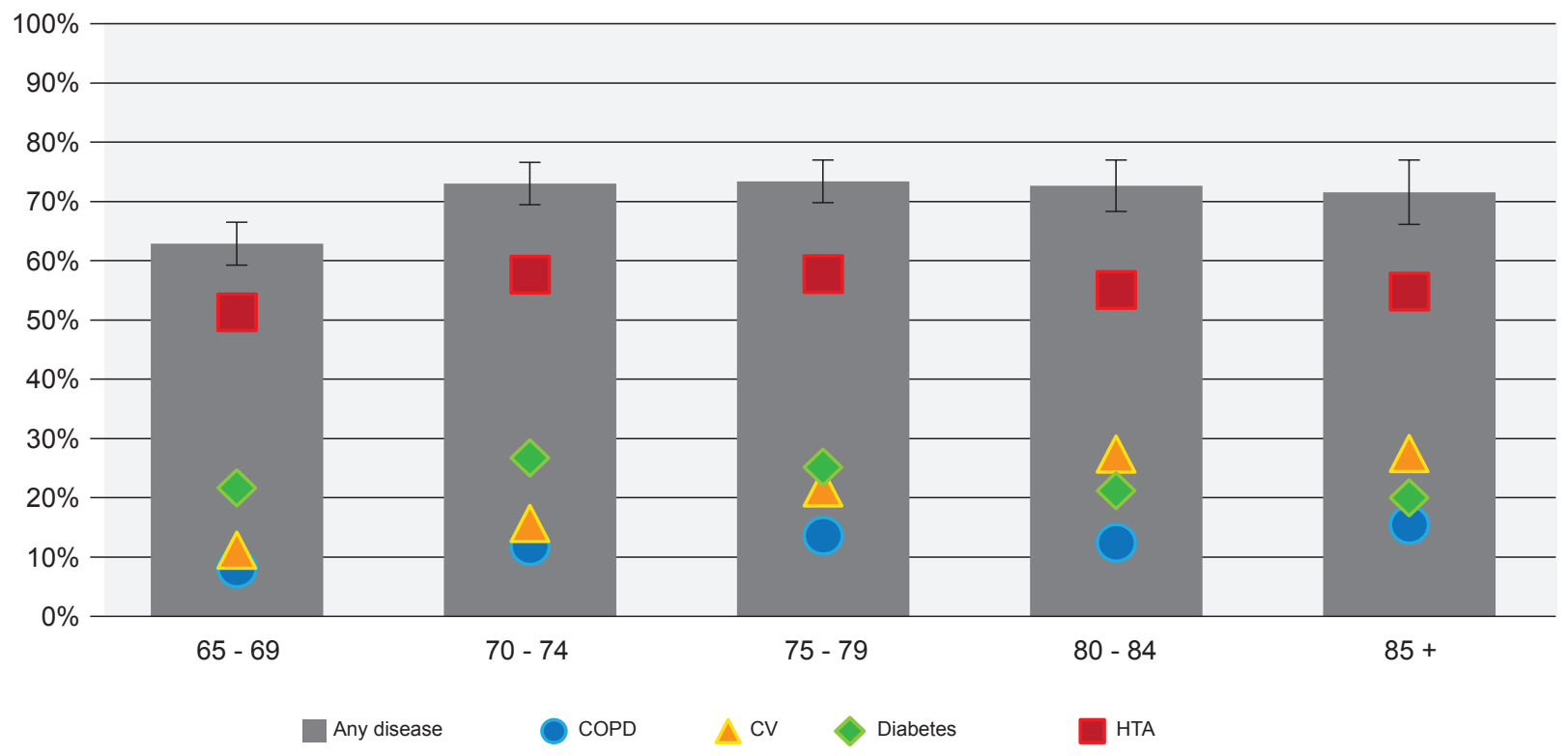

Figure 1 - Prevalence of at least one potential COVID-19 risk factor regarding morbidity in the Portuguese population Chronic conditions - COPD: chronic obstructive pulmonary disease; CV: cerebro \& cardiovascular disease; diabetes; or HTA: hypertension.

$\dagger$ : Population at risk values were obtained using official population data from census and will not fully agree with calculations made from raw data (INS database)

Table 1 - Prevalence of potential COVID-19 risk factors in the Portuguese population, according to gender, age-group and region

\begin{tabular}{|c|c|c|c|c|c|c|}
\hline & COPD & CV & Diabetes & HTA & $\begin{array}{c}\geq 1 \text { risk factor } \\
\text { (CV, HTA, DM, COPD) }\end{array}$ & Population at risk ${ }^{\dagger}$ \\
\hline \multicolumn{7}{|l|}{ Gender } \\
\hline Males & $11.1 \%$ & $17.5 \%$ & $25.6 \%$ & $50.0 \%$ & $67.6 \%$ & 628722 \\
\hline Females & $12.3 \%$ & $20.1 \%$ & $21.7 \%$ & $58.9 \%$ & $71.8 \%$ & 932131 \\
\hline \multicolumn{7}{|l|}{ Age group } \\
\hline $65-69$ & $8.2 \%$ & $11.2 \%$ & $21.7 \%$ & $51.4 \%$ & $62.9 \%$ & 389246 \\
\hline $70-74$ & $11.9 \%$ & $15.7 \%$ & $26.7 \%$ & $57.8 \%$ & $73.0 \%$ & 387039 \\
\hline $75-79$ & $13.7 \%$ & $21.7 \%$ & $25.2 \%$ & $57.8 \%$ & $73.4 \%$ & 312374 \\
\hline $80-84$ & $12.5 \%$ & $27.4 \%$ & $21.2 \%$ & $55.1 \%$ & $72.7 \%$ & 254503 \\
\hline $85+$ & $15.5 \%$ & $27.5 \%$ & $20.0 \%$ & $54.9 \%$ & $71.6 \%$ & 217506 \\
\hline \multicolumn{7}{|l|}{ Region } \\
\hline North & $11.6 \%$ & $18.7 \%$ & $25.0 \%$ & $58.3 \%$ & $72.8 \%$ & 536607 \\
\hline Center & $13.6 \%$ & $22.3 \%$ & $21.9 \%$ & $56.0 \%$ & $72.4 \%$ & 388867 \\
\hline Lisbon and Tagus Valley & $11.2 \%$ & $17.5 \%$ & $22.5 \%$ & $51.9 \%$ & $66.2 \%$ & 408564 \\
\hline Alentejo & $12.9 \%$ & $19.8 \%$ & $23.4 \%$ & $58.2 \%$ & $71.7 \%$ & 128826 \\
\hline Algarve & $9.1 \%$ & $17.7 \%$ & $19.6 \%$ & $52.0 \%$ & $65.9 \%$ & 62291 \\
\hline Azores & $12.7 \%$ & $20.7 \%$ & $30.1 \%$ & $54.8 \%$ & $74.3 \%$ & 26015 \\
\hline Madeira & $10.9 \%$ & $21.5 \%$ & $27.9 \%$ & $57.2 \%$ & $73.8 \%$ & 30979 \\
\hline National & $11.8 \%$ & $19.0 \%$ & $23.3 \%$ & $55.2 \%$ & $70.0 \%$ & 1560667 \\
\hline
\end{tabular}

Chronic conditions - COPD: chronic obstructive pulmonary disease; CV: cerebro \& cardiovascular disease; diabetes; or HTA: hypertension

† Population at risk values were obtained using official population data from census and will not fully match with calculations made from raw data (INS database) 
of all at-risk national population).

We observed statistical differences in the regional prevalence of risk factors. Northern Portugal not only has the highest prevalence of selected morbidity (72.8\%) within mainland Portugal, but also the largest population at risk for COVID-19 (33.7\%, Fig. 2), given its overall number of elderly population ( $n=723660 ; 32.5 \%$ of all national population above 65). The Algarve is the region with lowest risk $(65.9 \%)$ and lowest at-risk population share in mainland Portugal (4.0\%), while the Azores, despite the greatest risk $(74.3 \%)$ has the lowest number of people at risk in Portugal with a share of $1.7 \%$. (Fig. 2), given the lower number of elderly people $(n=35014 ; 1.6 \%$ of all the national population above 65). The detailed prevalence of each of the analyzed chronic conditions by region can be seen in Table 1 .

\section{DISCUSSION}

Even considering a restrictive definition of risk for severe COVID-19 illness, we estimated that 15.5\% ( $n=1560$ 667 ) of the Portuguese population might be at high risk for complications from COVID-19 because of both old age and pre-existing chronic conditions. Such estimates vary across the country. The largest share of population at risk is located in Northern Portugal due to having both high prevalence of these potential risk factors and its population size.
So far, this is in line with the geographical distribution of COVID-19 in Portugal, considering that the majority of deaths so far occurred in Northern Portugal (50.4\%, as of July 8,2020 , according to the Portuguese official data). ${ }^{17}$ In fact, it happened in a disproportional way, given that the national COVID-19 statistics show a much higher share in Northern Portugal compared to our projected results of population at-risk. ${ }^{17}$ This might be due to some other reasons, namely the larger initial epidemic found in this region, ${ }^{17}$ and perhaps due to other COVID-19 risk factors which are more prevalent in Northern Portugal compared to the national average.

Among the elderly, the expected share of population atrisk does not grow with age. First, because the population size decreases with age, and, secondly, because the prevalence of chronic diseases reaches its peak around the age of 70 (probably because people with the condition of interest are more likely to be selected out of the population). ${ }^{18}$ These results are in line with the already mentioned studies performed in the United States by Adams ML et al, ${ }^{12}$ and with what has been observed so far in the COVID-19 age distribution in Portugal. The proportion of population at the highest risk found in this study is below what others have estimated for population at increased/high risk, ${ }^{19,20}$ including Adams ML et al and Koma W et al (45.4\% and $37.6 \%$ of US

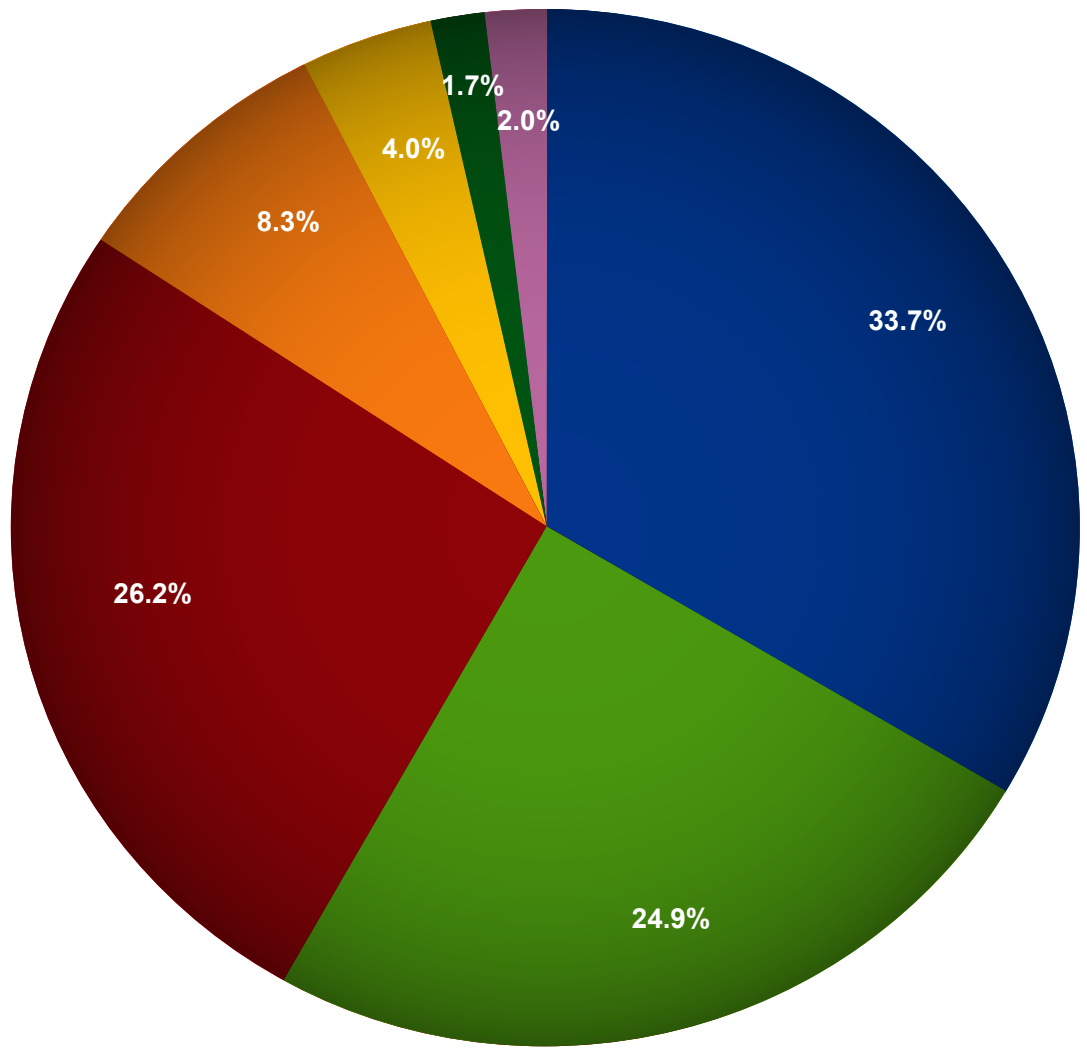


adults, respectively), ${ }^{11,21}$ which is mostly the result of adopting another definition of risk (i.e. old age or at least one underlying condition). In fact, in Appendix 1 (see Appendix 1: https://www.actamedicaportuguesa.com/revista/index. php/amp/article/view/14222/Appendix_01.pdf), where we used a less conservative definition of risk, the proportions become much closer (i.e. $41.8 \%$ share of Portuguese population above 15 years old).

When considering the prevalence of the analyzed risk factors, more women are affected than men, and, because there are approximately $40 \%$ more women than men over 65 in Portugal, ${ }^{22}$ the projected number of population at risk was also much higher in the female group. However, it is important to stress that a higher frequency of worse COVID-19 outcomes in males has been reported elsewhere..$^{23,24}$ Until now in Portugal, namely among the elderly, more women were infected than men, but men are more likely to be hospitalized and to die. ${ }^{17}$ This might be due to other risk factors unequally distributed by gender, which are not being taken in consideration in this analysis (e.g. plasma concentrations of angiotensin-converting enzyme 2 higher in men than in women). ${ }^{25}$ Further research should aim to understand this in more detail.

This study is hampered by some limitations that need to be stated. First, the analysis is based on self-reported data, which might be subject to recall bias and misclassification bias (e.g. chronic diseases not clinically confirmed). Furthermore, it is possible that underreporting might have taken place among those who consult less and/or are less aware of their own chronic conditions (e.g. low educated groups with lack of health literacy and awareness). Secondly, disease severity and staging were not taken in consideration, given that there is no such available data in the literature. Thirdly, the INS data included only noninstitutionalized adults and is from 2014, which likely leads to underestimation of results. The prevalence of the analyzed chronic diseases is expected to have increased in the meanwhile (for instance, Laires PA et al estimated a 3.1\% growth in the prevalence of multimorbidity between 2014 and 2020 in Portugal). ${ }^{26}$ However, in the population at-risk we have used the latest available official demographic data (2018) including institutionalized adults. Lastly, our study does not address possible differences in contracting the disease, but rather the risk for development of complications among individuals who have COVID-19 on the basis of results from the meta-analysis by Wang $\mathrm{B}$ et al. ${ }^{16}$ Certainly, there are several other relevant risk factors which could have been used to calculate the population at risk and alternative risk definitions would necessarily lead to different estimates of population at-risk. Given the current knowledge, we thus considered our definition, with a combined risk of age and selected morbidity, to be more appropriate namely to aid prioritization of health policies. Nonetheless, we do understand that a more restrictive definition of 'highest risk' may underestimate the real proportion of people at increased risk.

Additional evidence from well-designed studies is needed to explore further the association between comorbidities (and other relevant risk factors) and COVID-19 outcomes. Such knowledge can help to better define those at higher risk, and thus allow a more targeted and specific approach to prevent worse outcomes following COVID-19 infection. This is particularly true for high prevalent conditions, such as hypertension, where more evidence is still required regarding their association with COVID-19 severe disease. In fact, the need for better knowledge on risk factors has been recently highlighted by NEJM as one of key priorities for COVID-19 research. ${ }^{27}$

These findings should encourage authorities to continue to shield those who are more vulnerable to the pandemic threat, particularly in those areas of the country which are more likely to be more affected. Moreover, by doing so, it avoids the collapse of the healthcare system given the huge number of people at increased risk of developing serious disease in case of COVID-19 infection. It also calls for more research on the risk factors for COVID-19, specifically on the Portuguese population.

\section{CONCLUSION}

We projected a considerable number of Portuguese people at the highest risk for severe COVID-19 disease due to both old age and pre-existing chronic conditions. Such estimates vary across the country.

\section{PROTECTION OF HUMANS AND ANIMALS}

The authors declare that the procedures were followed according to the regulations established by the Clinical Research and Ethics Committee and to the Helsinki Declaration of the World Medical Association.

\section{DATA CONFIDENTIALITY}

The authors declare having followed the protocols in use at their working center regarding patients' data publication.

\section{COMPETING INTERESTS}

The authors have declared that no competing interests exist.

\section{FUNDING SOURCES}

This research received no specific grant from any funding agency in the public, commercial, or not-for-profit sectors.

2. Hui DS, Azhar El, Madani TA, Ntoumi F, Kock R, Dar O, et al. The continuing 2019-nCoV epidemic threat of novel coronaviruses to global health - The latest 2019 novel coronavirus outbreak in Wuhan, China. Int

\section{REFERENCES}

1. Huang C, Wang Y, Li X, Ren L, Zhao J, Hu Y, et al. Clinical features of patients infected with 2019 novel coronavirus in Wuhan, China. Lancet. 2020;395:497-506 
$J$ Infect Dis. 2020;91:264-66.

3. World Health Organization. COVID-19 Situation Report n¹69 [accessed $2020 \mathrm{Jul}$ 8]. Available from: https://www.who.int/docs/defaultsource/coronaviruse/situation-reports/20200707-covid-19-sitrep-169. pdf?sfvrsn=c6c69c88 2 .

4. Guan WJ, Ni ZY, Hu Y, Liang WH, Ou CQ, He JX, et al. Clinical Characteristics of Coronavirus Disease 2019 in China. N Engl J Med. 2020;382:1708-20.

5. Chen N, Zhou M, Dong X, Qu J, Gong F, Han Y, et al. Epidemiological and clinical characteristics of 99 cases of 2019 novel coronavirus pneumonia in Wuhan, China: a descriptive study. Lancet. 2020;395:507-13.

6. Wang D, Hu B, Hu C, Zhu F, Liu X, Zhang J, et al. Clinical characteristics of 138 hospitalised patients with 2019 novel coronavirus-infected pneumonia in Wuhan, China. JAMA. 2020;323:1061-9.

7. Shi H, Han X, Jiang N, Cao Y, Alwalid O, Gu J, et al. Radiological findings from 81 patients with COVID-19 pneumonia in Wuhan, China: a descriptive study. Lancet Infect Dis. 2020 (in press). doi: 10.1016/ S1473-3099(20)30086-4.

8. $\mathrm{Xu} X W$, Wu XX, Jiang $X G, X u K J$, Ying $L J, M a C L$, et al. Clinical findings in a group of patients infected with the 2019 novel coronavirus (SARSCov-2) outside of Wuhan, China: retrospective case series. BMJ. 2020;368:m606.

9. Zhou F, Yu T, Du R, Fan G, Liu Y, Liu Z, et al. Clinical course and risk factors for mortality of adult inpatients with COVID 19 in Wuhan, China: a retrospective cohort study. Lancet. 2020;395:1054-62.

10. Instituto Nacional de Estatística. Inquérito Nacional de Saúde 2014. INE. Lisboa: INE; 2016. [accessed 2020 Apr 29]. Available from: $\quad$ https://www.ine.pt/xportal/xmain?xpid=INE\&xpgid=ine publicacoes\&PUBLICACOESpub_boui=263714091\&PUBLICACOESm odo $=2$.

11. Instituto Nacional de Estatística INE. Lisboa: INE; 2016. [accessed 2020 Apr 29]. Available from: https://www.ine.pt/xportal/ xmain?xpid=INE\&xpgid=ine_indicadores\&indOcorrCod=0009098\&cont exto=bd\&selTab=tab2\&xlang=pt.

12. Adams ML, Katz DL, Grandpre J. Population-based estimates of chronic conditions affecting risk for complications from coronavirus disease, United States. Emerg Infect Dis. 2020 (in press).

13. Centers for Disease Control and Prevention. People who are at increased risk for severe illness. [accessed $2020 \mathrm{Apr} 29$ ]. Available from: https://www.cdc.gov/coronavirus/2019-ncov/need-extra-precautions/ people-at-higher-risk.html.

14. Sinclair AJ, Abdelhafiz AH. Age, frailty and diabetes - triple jeopardy for vulnerability to COVID-19 infection. EClinicalMedicine. 2020:100343.
15. CDC COVID-19 Response Team. Preliminary estimates of the prevalence of selected underlying health conditions among patients with coronavirus disease 2019 - United States, February 12-March 28, 2020. MMWR Morb Mortal Wkly Rep. 2020;69:382-6.

16. Wang $B$, Li R, Lu Z, Huang $Y$. Does comorbidity increase the risk of patients with COVID-19: evidence from meta-analysis. Aging. 2020;12:6049-57.

17. Ministério da Saúde. Relatório de situação. [accessed 2020 Jul 8] Available from: https://covid19.min-saude.pt/relatorio-de-situacao/.

18. Kaplan GA, Haan MN, Cohen RD. Risk factors and the study of prevention in the elderly: methodological issues. In: Wallace RB, Woolson RF, editors. Epidemiologic study of the elderly. 1992; New York: Oxford University Press. p. 20-36.

19. Clark A, Jit M, Warren-Gash C, Guthrie B, Wang HX, Mercer SW, et al. Global, regional, and national estimates of the population at increased risk of severe COVID-19 due to underlying health conditions in 2020: a modelling study. Lancet Glob Health. 2020 (in press). doi: 10.1016/ S2214-109X(20)30264-3.

20. Banerjee A, Pasea L, Harris S, Gonzalez-Izquierdo A, Torralbo A, Shallcross $L$, et al. Estimating excess 1 -year mortality associated with the COVID-19 pandemic according to underlying conditions and age: a population-based cohort study. Lancet. 2020;395:1715-25.

21. Koma W, Neuman T, Claxton G, Rae M, Kates J, Michaud J. How many adults are at risk of serious illness if infected with coronavirus? Washington: Kaiser Family Foundation; 2020.

22. Instituto Nacional de Estatística. População residente - 2019. [accessed $2020 \mathrm{Apr}$ 29]. Available from: https://www.ine.pt/xportal/ xmain?xpid=INE\&xpgid=ine_indicadores\&indOcorrCod $=0008273$.

23. Yi Y, Lagniton PN, Ye S, Li E, Xu RH. COVID-19: what has been learned and to be learned about the novel coronavirus disease. Int J Biol Sci. 2020;16:1753-66.

24. Zhang J, Yu M, Tong S, Liu LY, Tang LV. Predictive factors for disease progression in hospitalized patients with coronavirus disease 2019 in Wuhan, China. J Clin Virol. 2020;127:104392,

25. Sama IE, Ravera A, Santema BT, van Goor H, Ter Maaten JM, Cleland JG, et al. Circulating plasma concentrations of angiotensin-converting enzyme 2 in men and women with heart failure and effects of reninangiotensin-aldosterone inhibitors. Eur Heart J. 2020;41:1810-7.

26. Laires PA, Perelman J. The current and projected burden of multimorbidity: a cross-sectional study in a Southern Europe population. Eur J Ageing. 2018;16:181-92.

27. Lipsitch M, Swerdlow DL, Finelli L. Defining the epidemiology of covid-19 - studies needed. N Engl J Med. 2020;382:1194-6. 